\title{
北海道における自動車交通流動特性について
}

\section{Flow Characteristics of Inter-city Automobile Traffic in Hokkaido}

\author{
合月 孝* ・桝谷有三** ・加賀屋誠一 $* * * \cdot$ 斉藤和夫 $* * * *$ \\ By Takashi AITSUKI, Yuzo MASUYA, Seiichi KAGAYA and Kazuo SAITO
}

\section{1. まえがき}

北海道は都市間距離が長い広域分散型社会であるとと もに、代替交通が不十分なため、移動主体を自動車交通に 頼らざるを得ない自動車社会を形成している。このため、 自動車の交通圈、地域間の交流圈あるいは地域の空間構造 等を市町村間の自動車交通流動の面から考えることは重 要である。著者等は1、道路利用者のサービス水準を表す 指標のなかで最も基本的な指標である時間距離を基礎に 自動車交通流動の特性について分析を行ってきた。この研 究においては、交通流動としての自動車OD 交通及ひ洨通 抵抗としての時間距離を同時に考えることができる累積 頻度分布曲線の作成を基礎に、平均時間距離及び累積比率 の值等を通して種々考察が試みられてきた。

この累積頻度分布曲線によって、各市町村を発生・集中 している OD 交通はどの程度の時間距離以内の市町村と 結びつきを持っているか等を視覚的に、計量的に把握する ことはできる。しかしながら、各市町村のOD交通量は必 ずしも時間距離の順に減少しているわけではなく、時間距 離の離れた市町村とも多くの交流を図っている自動車OD 交通もある。また、平均時間距離は同じような值を取りな がらも OD分布状況が異なる場合もある。そこで本研究に おいては、既往の累積頻度分布曲線を基礎とした平均時間 距離に加え、他の市町村との交流規模及ひ交流範囲を視覚 的に、計量的に把握することができる指標として既往の OD 分布指標値も考えた ${ }^{2)}$ 。

本研究においては北海道 212 市町村のうち、離島を除く 208 市町村の 1989 年(平成 2 年)及び 1999 年(平成 12 年) の 2 年次の自動車 OD 交通を対象に分析を行う。そして、 既往の平均時間距離及びOD 分布指標值を基に、208 市町 村の自動車交通流動特性及び 2 年次間の交通流動の変化 等について分析を試みる。また、2つの指標值を基にクラ スター分析を行い、自動車交通流動特性から見た 208 市町 村の市町村区分についても分析を試みた。
さらに、本研究においては市町村間の自動車交通流動の 視点からみた市町村間の依存関係、すなわち市町村間の結 節構造の視覚化についても考察を試みた。結節構造の視覚 化に関する研究としては、直接車結法、グラフ理論法、因 子分析法あるいはクラスター分析法など種々の方法が提 案されている3)、4)。本研究においては、各市町村間の直接 的連結性だけを考慮する直接連結法及び自動車 OD 表(行 列)から作成される流出率行列を基に、各市町村間の機能 的結合関係の視覚化を図ることができる新たなアルゴリ ズムの開発を行った。その結果、流出率行列を基礎とした 簡単な行列演算を通して中心都市及ひ圈域の設定も容易 に行うことができた。さらに、1989 年及び 1999 年の $2 つ$ の年次を対象とした視覚化等を通して、自動車交通の面か らみた北海道の地域構造の変容過程についても考察する ことができた。

そして、これらの研究を通して、生活様式の都市化ある いはモータリゼーションの進展に伴う各市町村の自動車 交通流動の変化、さらには自動車交通流動の変化が各市町 村間の機能的結合関係あるいは都市圈の形成とその変容 過程に及ぼす影響等を視覚的に把握することができる。そ の結果、高規格幹線道路網等の整㣁が市町村間の交流可能 性及び道路利用者の利便性をどの程度増大させているか を把握することができる。

\section{2. 平均時間距離及びOD 分布指標值こついて}

平均時間距離は、自動車OD交通及ひ時間距離を同時に 考えることができる累積頻度分布曲線を基に算定を行っ $た^{1)}$ 。今、各市町村間の OD 交通量を $f_{i \curvearrowright}$ 市町村 $i$ の全 発生交通量を $F_{i}\left(=\Sigma f_{i j}\right)$ したとき、流出率 $r_{i j}$ は式 (1) で求めることができる。この流出率は、発市町村 $i$ からの $F_{i}$ のうちどれほど着市町村 $j$ 一向からかを表すもので、市 町村間の自動車交通流動の視点から見たときの発市町村 $i$ の着市町村 $j$ への依存度(重要度)を示す指標でもある。

$$
r_{i j}=f_{i j} / F_{i}
$$

キーワード : 自動車交通流動、OD 分布指標、結節構造、北海
* 学生員 北海道大学大学院工学研究科都市噮境工学専攻

（札幌市北区北 13 条西 8丁目 TEL011-706-6212 Fax011-706-6211）

** 正会員 工博 専修大学北海道短期大学教授 境境システム科

***フェロー 学博 北海道大学大学院工学研究科教授 都市環境工学専攻

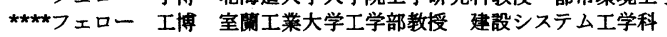

そうすると、図一 1 に示すように累積頻度分布曲線は、 横軸に市町村間時間距離を、緹軸に全ての着市町村への 


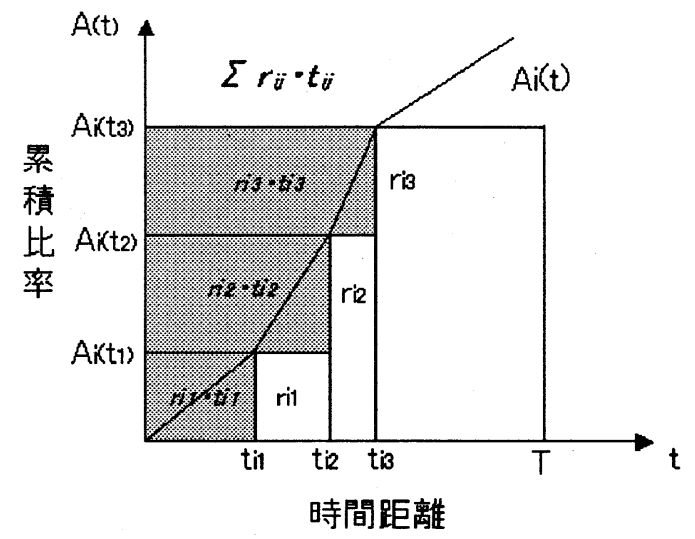

図-1 平均時間距離算定の概念図

自動車 OD 交通のうち、ある時間距離以内に到達可能な OD 交通量に対する流出率の和 (累積比率) によって作成 することができる。すなわち、対象とする発市町村 $i$ の累 積頻度分布曲線は、対象とする発市町村 $i$ と着市町村 $j$ 間 の時間距離 $t_{i j}$ によって着市町村 $j$ を並びかえるとともに、 並びかえられた着市町村 $j$ までの流出率の和を求めるこ とによって作成できる。また、作成された曲線を基淮に、 縦軸及ひ横軸の時間距離 $\mathrm{T}$ に対する累積流出率 $A_{i}(T)$ で囲 まれた面積值が平均時間距離となる。これより、図一 1 に 示すように各市町村一の時間距離を $t_{i j}$ 流出率を $r_{i j}$ とす ると、ある時間距離T以内に到達可能な $\mathrm{OD}$ 交通の平均時 間距離 $M F_{i}{ }^{T}$ は式 (2) によって求めることができる。

$M F_{i}{ }^{T}=\sum_{i \in J_{i}{ }^{T}} r_{i j} \cdot t_{i j} / A_{i}(T)$

$J_{i}{ }^{T}$ : 発市町村 $i$ から時間距離 $T$ 以内に到達可能な市町村の集合

図一2は、北海道における4都市を対象に累積頻度分布 曲線を作成した例である。各都市の平均時間距離は、表一 1に示した。これらの例からも累積頻度分布曲線を通して、 各市町村を発生・集中している自動車OD 交通がどの程度 の交通抵抗（時間距離等）を克服しながら他の市町村と結 びつきをもって交通流動を行っているかについて視覚的、 計量的に把握することはできる。しかしながら、図一2に 示寸例のように各市町村の OD 交通は必ずしも時間距離 の順に減少しているわけではなく、時間距離の離れた市町 村とも多くの交流を図っている自動車OD交通もある。ま た、平均時間距離は同じような值を取りながら OD 分布状 況が異なる場合もある。

そこで本研究においては、式（2）に示す平均時間距離 に加え、他の市町村との交流規模及ひ洨流範囲を視覚的に、 計量的に把握することができる指標として既往の OD 分 布指標值も考えた ${ }^{2)}$ 。この OD 分布指標値算定の概念図が 図一3である。図の横軸には各市町村の順位の累積比率を、

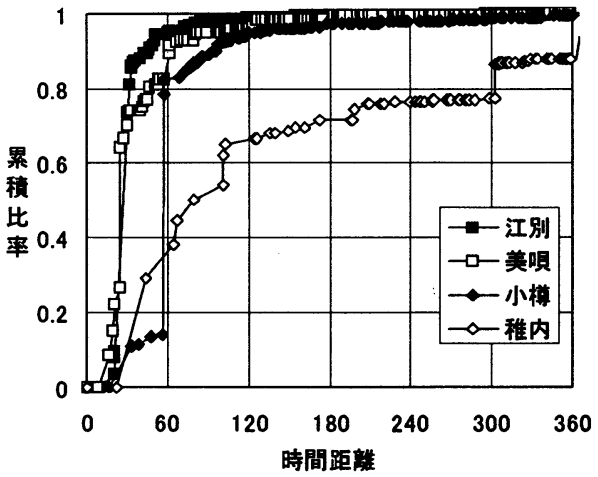

図一2 各市町村の累皘頻度分布曲線

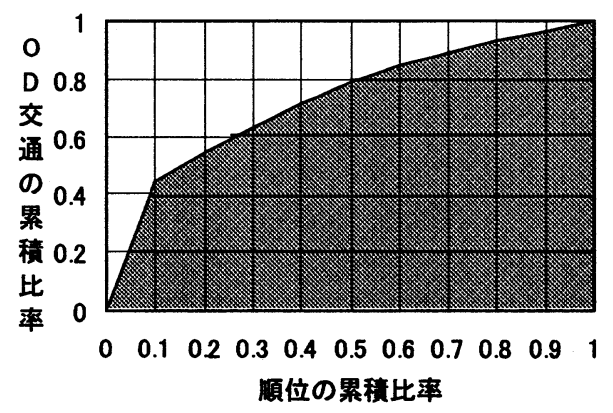

\section{図-3 OD分布指標値算定の概念図}

縦軸には対象とする発市町村から着市町村への自動車OD 交通のうち、ある順位以内の流出率の和 (累積比率) を表 している。図一3に示寸累積頻度分布曲線は以下の手順に よって作成できる。

1）対象市町村における着市町村一の流出率を大小順に並 ひ替える。ここでは、上位20の着市町村について取りあ げる。

2）上位 20 の着市町村の流出率に対する相対比率(二流 出率/上位 20 市町村への流出率の和)を求める。

3）並ひ譛えられた着市町村の順位までの相対比率に対 する累積比率を求める。

4）順位の累積比率を横軸、流出率に対する累積比率を 縦軸に、それぞれ各市町村の值をプロットする。

なお、ここでは対象市町村の数及び各市町村間の流出率 の值等を踏まえて、各市町村の指標値の相違を明らかにす るため、OD 交通量が上位 20 位までの市町村を対象に指 標値算定を行った。

OD 分布指標値は、図一 3 に示寸累積頻度分布曲線及び 横軸の累積比率1.0に対する縦軸で囲まれた面積值として 算定することができる。また、面積值は敌形公式を通して 容易に求めることができる。そして、この指標値は 0.5 か ら 1.0 の範囲の值を取り、交流の規模が大きい市町村があ るとき、すなわち OD 交通量の值が大きい市町村がある時、 


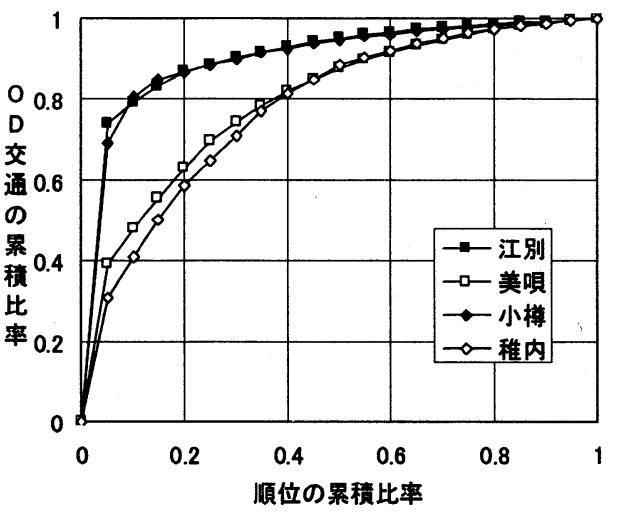

図-4 各市町村のOD分布指標值

\section{表ー1＼cjkstart各市町村の交通流動に関する指標値}

\begin{tabular}{c|cccc}
\hline & 江別 & 美唄 & 小模 & 稚内 \\
\hline OD交通量 & 34625 & 7700 & 38617 & 2709 \\
平均時間距離(分) & 35.6 & 37.4 & 67.1 & 147.0 \\
OD分布指橙值 & 0.9045 & 0.7962 & 0.9008 & 0.7802 \\
\hline クラスタ一区分 & $\mathrm{I}$ & $\mathrm{II}$ & $\mathrm{V}$ & $\mathrm{VI}$ \\
\hline
\end{tabular}

曲線も左側へシフトし 1.0 に近い值を取る。一方、多くの 市町村と同じ程度の交流を行っている場合は、曲線も右側 ヘシフトし 0.5 に近づていく。

図一 4 は、図一 2 に示㨋市を対象に OD 分布指標値に 対する累積頻度分布曲線を作成した例である。また、表一 1 にはOD 分布指標值を示した。これらの例からも、OD 分布指標值を通して、同じ平均時間距離の值を取りながら $\mathrm{OD}$ 分布状況が異なる市町村、各市町村が他の市町村とど の程度の規模の交流を図っているのか、あるいはどの程度 の市町村と交流を図っているか等を視覚的に、計量的に把 握することができる。

\section{3. 市町村間の結節棈造の視賞化}

本研究における結節構造の視覚化は、各市町村の地理的 位置関係を踏まえて地図上に各市町村間の結合関係を図 示しようとするものである。このためには、市町村間の結 合関係が有意か㧵かを判断する基準值の設定とともに、基 準值を基にした行列表現が必要である。そこで、本研究で は自動車 OD 行列から作成される流出率行列の各行(市町 村)ごとに、流出率の最大值 (以下、最大流出率という) を 求める。そして、この最大流出率を取る市町村間の要素を 1 に、他の要素を全て 0 とする依存度行列を作成して結節 構造の視覚化を試みた。

また、流出率行列から算定される各市町村の流出率の和 及び依存度行列から求められる入度数等を基に中心都市 の設定を行うとともに、圈域の設定及び中心都市を中心と

\begin{tabular}{c|cccc|c}
\multicolumn{7}{c}{$(1)$ OD表 } \\
\hline A & A & B & C & D & 合計 \\
\hline B & 0 & 10335 & 3630 & 850 & 14815 \\
C & 850 & 0 & 2890 & 39 & 3779 \\
D & 4867 & 106 & 0 & 2999 & 7972 \\
\hline 合計 & 16009 & 19 & 102 & 0 & 16130 \\
\hline
\end{tabular}

(2) 流出率行列

\begin{tabular}{c|cccc|c}
\hline & $\mathrm{A}$ & $\mathrm{B}$ & $\mathrm{C}$ & $\mathrm{D}$ & 合計 \\
\hline $\mathrm{A}$ & 0 & 0.6976 & 0.245 & 0.0574 & 1 \\
$\mathrm{~B}$ & 0.2249 & 0 & 0.7648 & 0.0103 & 1 \\
$\mathrm{C}$ & 0.6105 & 0.0133 & 0 & 0.3762 & 1 \\
$\mathrm{D}$ & 0.9925 & 0.0012 & 0.0063 & 0 & 1 \\
\hline 流出曶和 & 1.8279 & 0.7121 & 1.0161 & 0.4439 &
\end{tabular}

\begin{tabular}{l|lllll}
\hline 流出率の和 & 1.8279 & 0.7121 & 1.0161 & 0.4439
\end{tabular}

(3) 依存度行列

\begin{tabular}{c|cccc}
\hline & $\mathrm{A}$ & $\mathrm{B}$ & $\mathrm{C}$ & $\mathrm{D}$ \\
\hline $\mathrm{A}$ & 0 & 1 & 0 & 0 \\
$\mathrm{D}$ & 0 & 0 & 1 & 0 \\
$\mathrm{C}$ & 1 & 0 & 0 & 0 \\
$\mathrm{D}$ & 1 & 0 & 0 & 0 \\
\hline 入度数 & 2 & 1 & 1 & 0 \\
\hline
\end{tabular}

（4）結節構造を考慮した依存度行列

\begin{tabular}{l|llll}
\hline & A & D & C & B \\
\hline A & 0 & 0 & 0 & 0 \\
D & 1 & 0 & 0 & 0 \\
C & 0 & 1 & 0 & 0 \\
B & 1 & 0 & 0 & 0 \\
\hline
\end{tabular}

（5）樹状図

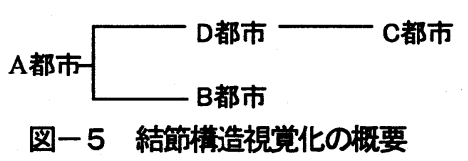

した市町村の階層構造 (樹状図)についても考察を行った。 いま、対象とする市町村数を $n$ としたき、流出率行列 $R$ 及 び依存度行列 $\boldsymbol{Q}$ は、それぞれ $(n \times n)$ 行列である。結節構 造の視覚化の手順は以下となる。

（1）式 (1) から算出される各市町村間の流出率 $r_{i j}$ を 基に、流出率行列を作成する。

（2）他の市町村からの当該市町村への依存程度を求める ため、各列(市町村)ごとに流出率の和を求める。

（3）各市町村(行)ごとに、最大流出率の值を求める。

（4）最大流出率を取る市町村間を 1 に、他の要素を全て 0 とする依存度行列を作成する。

（5）他の市町村からの当該市町村への依存程度を求める ために、依存度行列において各列 (市町村) ごとに要素 1 の数の和としての入度数を求める。

次に、作成された依存度行列を基に中心都市、圈域及び 圈域を構成する市町村の設定等に関する手順は以下となる。 (1)各市町村の流出率の和の值のうち、最も大きい市町村の 行を最初の行に並びかえる。

(2流出率の值が最も大きい市町村を対象に、当該市町村に 依存している市町村、すなわち依存度行列における当該 
市町村の列において要素 1 を取る市町村を取りあげる。

(3)取りあげられた市町村 (行) を入度数の大小順に、当該 市町村の次の行に順次並ひ変える。

(4)手順(3)の入度数の順に、手順(2)と同様にそれぞれの市町 村に依存している市町村を依存度行列から求める。

(5)取りあげられた市町村 (行) を手順(3)と同様に、入度数 の順に並びかえる。

(6)手順(2) (5)において取りあげられた市町村において、そ れぞれの市町村に依存している市町村があるまで手順 (2)〜(5)を繰り返す。

(7)手順(1) (6)において取りあげられていない市町村のう

ち、流出率の和が最も大きい市町村を取りあげて、手順 (2)〜(6)を行う。

(8)対象とする市町村がいずれかの圈域に属するまで、手順 (2)〜(7)を繰り返す。

(9)手順(1) 8)において並ひかえられた行 (市町村) の順に、 列（市町村）の順も並びかえる。

(10)手順(9)で作成された依存度行列において要素 1 を取る 市町村間、すなわち行の市町村から列の市町村一依存関 係があるとして図示化を行う。

このような手順を通して、各市町村間の流出率を踏まえ た結節構造の視覚化を図ることができる。ここで手順(1)及 び手順(つにおいて取りあげられた市町村が中心都市である。 また、手順(2) (6)において取りあげられた市町村がそれぞ れの中心都市を中心に圈域を構成する市町村となる。さら に、各圈域ごとに各市町村が取りあげられた順序及び各市 町村間の依存関係を基に階層構造としての樹状図を作成 することができる。図一5には、4都市の自動車 OD 表を 例として流出率行列、依存度行列、結節構造を考虑した依 存度行列及ひ稿状図を示した。ここで、OD 表のなかで対 角要素を 0 、すなわち内々交通を除いたのは、各市村を発 生・集中している自動車OD 交通が市町村の行政区域を超 えて、どの程度の広域的な交流・連携を図っているかを、 より明らかにするためである。

\section{4. 北海道の自動車交通流動特性について}

\section{（1）平均時間距離及びOD分布指標值について}

本研究においては、後述の図一9に示す北海道212 市町 村のうち離島を除く 208 市町村を対象に分析を試みた。分 析に用いたデータは、1989 年及び 1999 年に実施された全 国交通状勢調査の市町村間自動車 OD 表及び各市町村間 の時間距離である。208 市町村を対象に平均時間距離及び OD 分布指標值に対するそれぞれの累積頻度分布曲線を作 成（例 : 前述の図一 2 及ひ図-4）するととともに、各指 標値の算定を行った結果を取りまとめたのが表一 2 及び 図一6、図ー7である。

2 年次間の平均時間距離の変化を見ると、1989 年から

\section{表-2 平均時間距離とOD分布指標值}

\begin{tabular}{c|cc|cc}
\hline \multirow{2}{*}{ 項目 } & \multicolumn{2}{|c|}{ 平均時間距離(分) } & \multicolumn{2}{c}{ OD分布指標値 } \\
\cline { 2 - 5 } & 1989 年 & 1999 年 & 1989年 & 1999 年 \\
\hline 平均值 & 49.5 & 58.4 & 0.8715 & 0.855 \\
最大值 & 147.0 & 198.2 & 0.9608 & 0.9632 \\
最小值 & 17.5 & 22.8 & 0.6991 & 0.7113 \\
標準偏美 & 20.3 & 22.8 & 0.0503 & 0.0544 \\
\hline
\end{tabular}

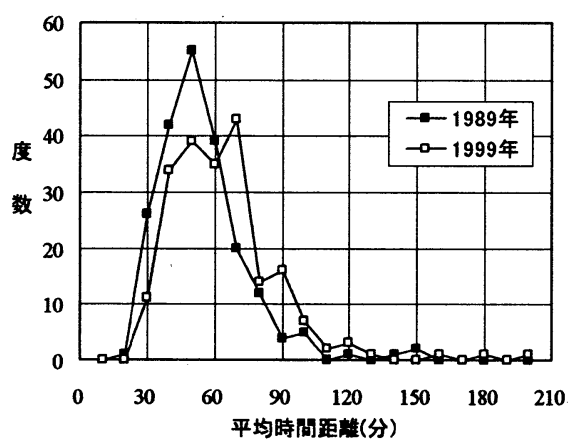

図一6 平均時間距離の頻度分布

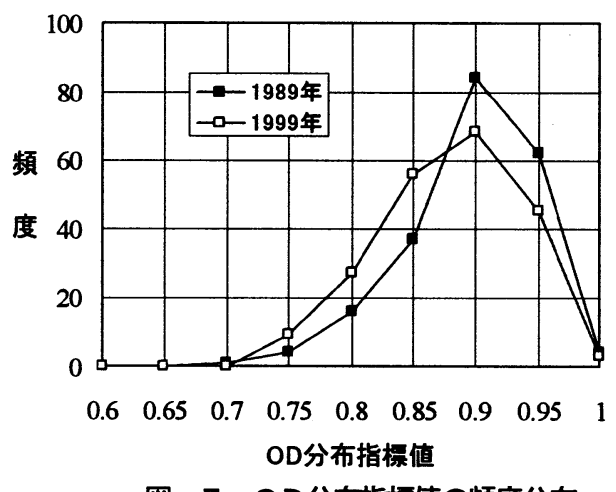

図-7 OD分布指標値の頻度分布

1999 年にが全体的に増加している。特に、1989 年に おいて、平均時間距離が 60 分以下の市町村は 208 市町村 のうち 163 市町村と全体の 78\%を占めていたが、1999 年 には119市町村 (57\%) に減少している。一方、平均時間 距離 60 90 分の市町村は 36 市町村 (17\%) から 73 市町 村 (35\%) に増加している。また、OD 分布指標値の変化 を見ると、1989 年から 1999 年にかけて全体的に減少して いる。区間ごとに見ると OD 分布指標值が 0.85 以下の区 間では 1989 年から 1999 年にかけて度数は増加しており、 反対に 0.85 以上の区間では减少している。このように、 北海道における 10 年間の自動車交通の変化を見ると、平 均時間距離の増加及び $\mathrm{OD}$ 分布指標値の减少、すなわち全 体的にトリップ長の増大が窥える。

\section{（2）クラスター分析による交通流動特性の分析}

各市町村の自動車交通流動の相違を、平均時間距離及び OD 分布指標値を通して把握するため、2つの指標値を 
プロットした結果が図ー8である。ここでは 1989 年及び 1999 年の計 416 個のデータをプロットした。平均時間距離 と同時にOD 分布指標值を用いることで、各市町村の交通 流動変化を時間距離だけでなく、OD 分布状況の変化をも 考慮し把握することが可能となる。これら 2 つ指標值か ら各市町村の自動車交通流動の相違を把握するためクラ スター分析を行い、図ー8に示すように6つのクラスター に区分した。ここでは、図一9に示す 1989 年における各 市町村の区分状況を通して、各クラスター（以下「C」 とする）の特徵の把握を試みる。

-C-I (78 市町村): 平均時間距離力゙短く OD 分布指標值 が大きい、すなわち時間距離の短い市町村への交通規模が 大きい市町村が分類されている。分類された市町村は地方 中核・中心都市への依存度が大きい衛生都市的な市町村が 多い。石狩市、釧路町などの地方中核・中心都市に隣接す る市町村では、全体の交通の 7 割以上が地方中核・中心都 市に集中している。積丹町、別海町など発生交通量が 5000 未満と小さく地方中核・中心都市から離れた市町村では、 1 市町村ではなく複数市町村 (3〜 4市町村) で全体の交 通の8割以上を占める市町村が多い。

-CDII (62 市町村): 平均時間距離は短いが OD 分布指標 值は C-Iほど大きくない。分類された市町村は北海道全 体に広く分布しているが、いずれの市町村も地方中核・中 心都市と時間距離が 30 分以上離九ており、C-I ほどの極 端な集中傾向は見られない。しかし、時間距離 60 分に対 する累積比率の平均が 8 割を超えており、概ね時間距離 60 分以内の市町村と多く交流を図っていることが窥える。

-C一III (21 市町村) : OD 分布指標值が小さく、様々な市町 村と同程度の交流を図っている市町村が分類されている。 分類された市町村は旭川市、帯広市などの地方中核・中心 都市及ひ道央圈の市町村などである。道央圈の市町村では 地理的に近隣の市町村と広い交流を図りやすいため平均 時間距離が短い。また、地方中核・中心都市や道東・内陸 地方では、時間距離の長い市町村とも交流を図っているた め平均時間距離が長くなる傾向がある。

-C-IV(19 市町村) :C一Iに比べ平均時間距離が長く、 $\mathrm{OD}$ 分布指標值は $\mathrm{C}-$ II と同程度である。分類された市町 村は札幌市、函館市、釧路市などの地方中核・中心都市を 始め、道北地方の市町村などである。発生交通量 10000 以 上の札幌市、函館市などの地方中核・中心都市はC-IIIに 分類された市町村ほどではないが幅広い交流を図ってい る。また、発生交通量 5000 未満の市町村についてはいず れも地方中核·中心都市との時間距離が 60 分以上と長く、

また、時間距離 60 分に対する累積比率の平均は 8 割に達 していないため、 $\mathrm{C}$ 一I より平均時間距離が長くなってい ると考えられる。

-C-V (17 市町村) : C - I に比べ平均時間距離が長く、 OD 分布指標值が大きい。分類された市町村は猿扎村、厚

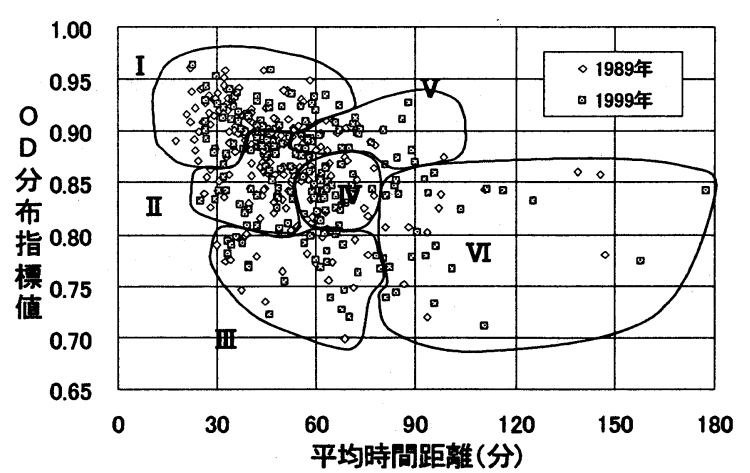

図ー8 クラスター分析による市町村区分

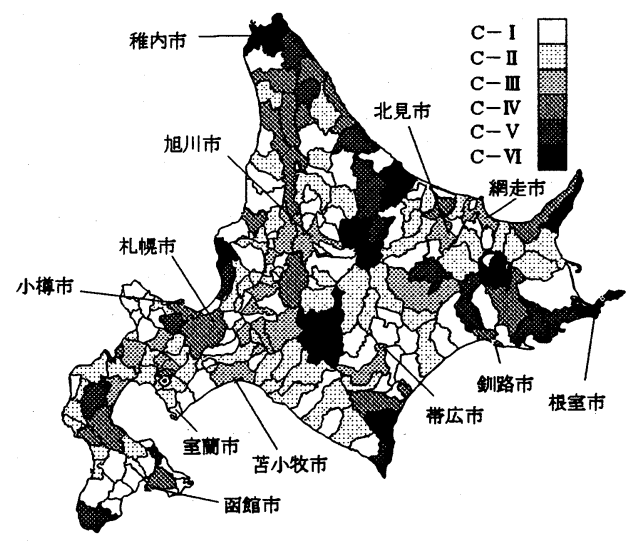

図一－クラスター分析による市町村区分（1989 年）

岸町、浜益村など、いずれも発生交通量が 5000 末满とな り、地理的にみると道北、道東、沿岸部に位置している。 $\mathrm{C}-\mathrm{I}$ と同様、特定の 1 市町村に集中寸る場合と複数の市 町村に集中する場合に大別され，前者に関しては交通が集 中しているのは時間距離が 60 90 分の地方中核・中心都 市である。後者に関しては、最も交通規模が大きい市町村 は隣接する市町村だが、それに次ぐ市町村に時間距離 90 分以上の地方中核・中心都市が含まれるため平均時間距離 が長くなっている。

$\cdot \mathrm{C}-\mathrm{VI}$ (11 市町村): OD 分布指標值の值は幅広いが、平均 時間距離が 80 分以上と長い市町村が分類されている。い ずれの市町村も発生交通量が 5000 未満と小さく、沿岸部 や内陸に位置し、地理的位置関係からも時間距離の長い市 町村と交流を行わなければならない。また、OD 分布状况 をみても時間距離 120 分以上の地方中核・中心都市への交 通が多く、平均時間距離が長くなっている。

表一 3 は、1989 年及び 1999 年における各クラスターに 属する市町村の数を取りまとめたものである。1989 年から 1999 年における各市町村のクラスターの移動を見ると、同 じクラスターに属する市町村は 105 市町村である。一方、 他のクラスターへ移動した市町村は 103 市町村となり、他 のクラスターへ移動した市町村の移動パターンは合計で 
表ー3 1989 年から 1999 年にかけてのクラスター変化

\begin{tabular}{|c|c|c|c|c|c|c|c|}
\hline 1989年 \1999年 & $C-I$ & $c-$ II & c-III & $C-I N$ & $c-v$ & $c-V$ & 棇数(1989年) \\
\hline$c-1$ & 43 & 19 & 0 & 7 & 9 & 0 & 78 \\
\hline$C-$ II & 2 & 25 & 7 & 21 & 5 & 2 & 62 \\
\hline$c-$ III & 0 & 1 & 15 & 1 & 0 & 2 & 19 \\
\hline $\mathrm{C}-\mathrm{IV}$ & 1 & 1 & 4 & 4 & 2 & 9 & 21 \\
\hline$c-V$ & 3 & 0 & 0 & 2 & 9 & 3 & 17 \\
\hline $\mathrm{C}-\mathrm{VI}$ & 0 & 0 & 0 & 0 & 2 & 9 & 11 \\
\hline 総数 (1999年) & 49 & 46 & 26 & 35 & 27 & 25 & 208 \\
\hline
\end{tabular}

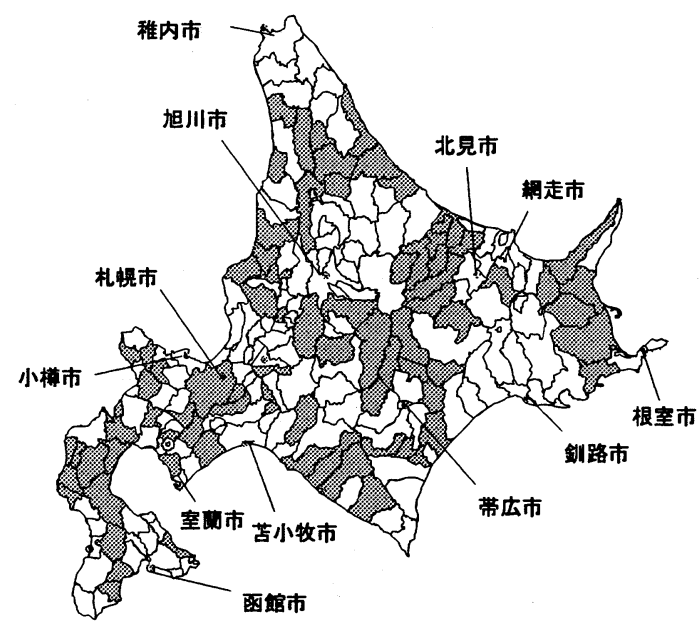

\section{図一10 平均時間距離の増加及び OD分布指標值か減少した 82 市町村}

20 パターンとなった。1989 年から 1999 年における各クラ スターの分類市町村数の変化を見ると平均時間距離が短 いクラスターである C-I、C-IIでは分類市町村数は减 少し、その他のクラスターでは増加㑯向にある。他のクラ スターへ移動した103市町村について平均時間距離の増减、 OD 分布指標値の増減について見ると、図一10 に示す 82 市町村 $(80 \%)$ で平均時間距離が増加し、OD 分布指標值 が減少している。

各指標値の変化からも理解できるように、クラスター間 の移動の多くは、より時間距離の長い市町村と同程度の交 流を図るような変化であることが窥える。特に、移動の要 因として地方中核・中心都市への交通量変化が大きく影響 していることが挙げられる。地理的に地方中核・中心都市 から遠く、1989 年において時間距離 60 分以内の近隣市町 村との交流が大部分を占めていた市町村では、時間距離が 180 分以上離れた地方中核・中心都市と直接交流を図る傾 向が見られる。また、地方中核・中心都市と比較的近くに 位置し、近距離の地方中核・ 中心都市一交通が集中する傾 向のあった市町村では、交通集中が緩和し時間距離の長い 他の地方中核・中心都市とも交流を図っている。

\section{（3）結節構造の視覚化}

1989 年及び 1999 年それぞれの自動車 OD 表を対象に、 各市町村ごとに着市町村への流出率を求めて流出率行列

\section{表ー4 主要都市における流出率の和及び入度数}

\begin{tabular}{|c|c|c|}
\hline 市町村名 & 1989 年 & 1999 年 \\
\hline 札瀑市 & $11.24(12)$ & $13.17(16)$ \\
\hline 旭川市 & $10.53(11)$ & $10.86(12)$ \\
\hline 带広市 & $8.21(15)$ & $7.56(14)$ \\
\hline 函館市 & $7.38(8)$ & $8.22(11)$ \\
\hline 鍃路市 & $6.08(10)$ & $6.44(9)$ \\
\hline 北見市 & $5.31(7)$ & $6.12(8)$ \\
\hline 滰川市 & $3.41(4)$ & $3.54(4)$ \\
\hline
\end{tabular}

表-5 圈域市町村数の変化

\begin{tabular}{|c|c|c|}
\hline 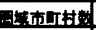 & 1989年(30.再域) & 1999年(27一埼) \\
\hline 30以上. & then: 故 (34) & 相期的(38) \\
\hline $10 \sim 29$ & 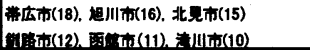 & 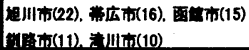 \\
\hline $5 \sim 9$ & 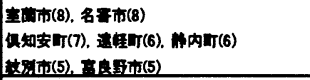 & 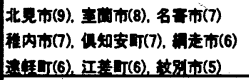 \\
\hline 4 & 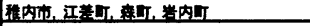 & 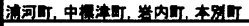 \\
\hline 3 & 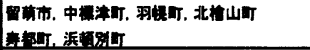 & 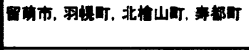 \\
\hline 2 & 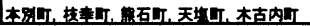 & 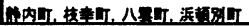 \\
\hline
\end{tabular}

$\boldsymbol{R}$ を作成するとともに、各市町村の最大流出率の值を基に 依存度行列 $\boldsymbol{Q}$ の作成を行った。また、それぞれの行列を基 に各市町村の流出率の和及び入度数の算定も行った。表一 4は、主要都市における流出率の和及び入度数の值を取り まとめたものである。1989 年及び 1999 年いずれも流出率 の和の值が最も大きい市町村が札幌市(11.24、13.17)であ ることから、いずれの年次とも札幌市を最初の中心都市と して設定した。そして、3. の手順(1) (10にしたがって、 流出率の和及び入度数を基に順次中心都市、圈域及ひ圈域 を構成する市町村の設定を行った。

表一 5 は、1989 年及び 1999 年それぞれの年次において 設定された中心都市、中心都市を中心として設定された圈 域及び圈域を構成する市町村数について取りまとめたも のである。圈域数(中心都市数)は、1989 年の 30 圈域から 1999 年の 27 圈域に减少している。札幌市、旭川市及ひ函 館市等の主要都市を始め 24 都市はいずれの年次とも中心 都市となっている。一方、それぞれの年次において中心都 市である市町村は、1989 年では富良野市、熊石町及ひ天塩 町等の 6 市町村、1999 年では網走、八雲、浜頓別の 3 市町 村である。このなかで、富良野市は 1999 年に旭川市の圈 域に組み込まれ、一方網走市は 1989 年の北見市の圈域か ら新たな圈域を構成している。

また、各圈域を構成する市町村数は札幌市の 34 市町村 (1989 年)から 38 市町村(1999 年)、旭川市 (16 市町村から 22 市町村) 及ひ函館市(11 市町村から 15 市町村)等のよう に主要都市において増加している。一方、北見市は網走市 の新たな圈域に伴って 15 市町村から 9 市町村に減少して いる。これら圈域を構成する市町村を始め、各市町村の依 存関係としての結節構造の視覚化が図一11 (1989 年)及び 図-12(1999 年)である。なお、図-11 及び図-12 におい ては、中心都市及び札幌市、旭川市の圈域を構成する市町 


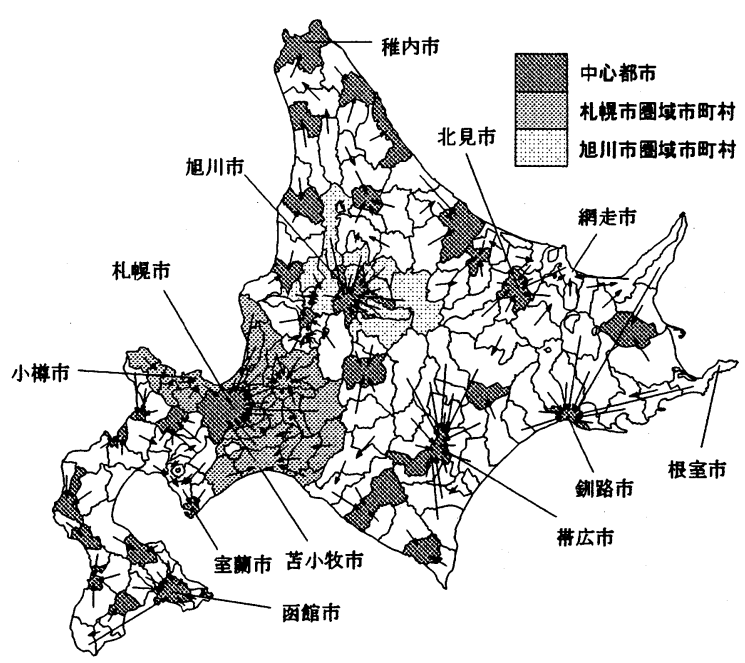

図一11 1989 年における結節構造

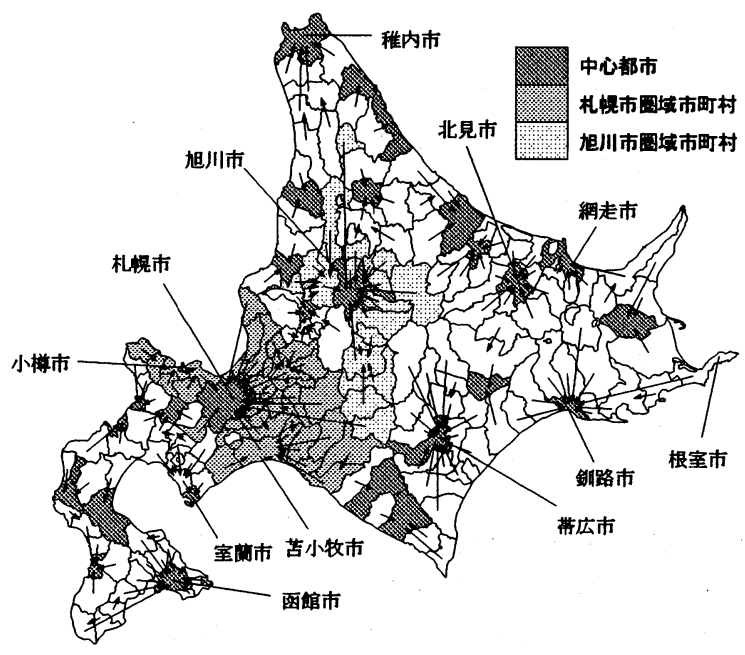

図ー12 1999 年における結節構造

村を濃淡図で示した。これらの図を通して、自動車交通の 流動特性から見た北海道における市町村間の結節構造及 ひ圏域の規模等を視覚的に容易に把握することができる。 また、2年次間の比較検討から結節構造の変容過程につい ても視覚的に把握することができる。

さらに、図一13(1989 年)及び図一14(1999 年)は札幌市 を中心都市として圈域を構成している市町村を対象に作 成した樹状図である。この樹状図を通して、圈域を構成し ている市町村間の依存関係を視覚的に容易に把握するこ とができる。圈域を構成している市町村数は、前述のよう に34 市町村から 38 市町村に堌加しているが、札幌市に直 接依存している市町村も 12 市町村から 17 市町村に増加し ている。表一6は、1999年に新たに札幌市の圈域に組み

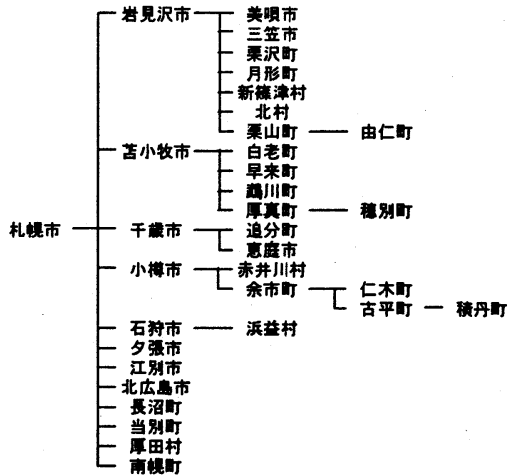

図ー13 1989 年における札幌市圈域市町村の構造

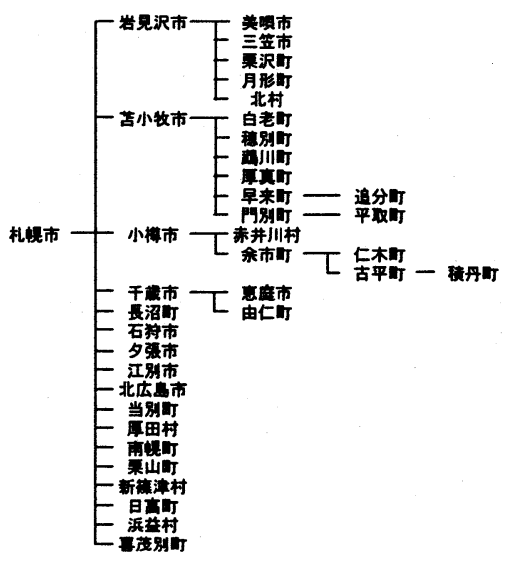

図ー14 1999 年における札靦市圈域市町村の構造

表ー6 5市町村の交通流動に関する指標值

\begin{tabular}{|c|c|c|c|c|c|c|}
\hline & \multicolumn{2}{|c|}{ 平均時间距離 } & \multicolumn{2}{|c|}{ OD分布指檡伹 } & \multicolumn{2}{|c|}{ 杜措への流出疅 } \\
\hline & 1989年 & 1999年 & 1989年 & 1999年 & 1989年 & 1999年 \\
\hline 棵山町 & 36.19 & 39.69 & 0.7976 & 0.7676 & 0.1154 & 0.1735 \\
\hline 新熦津村 & 33.79 & 39.25 & 0.8583 & 0.8080 & 0.1630 & 0.2422 \\
\hline 日高町 & 88.08 & 125.49 & 0.8063 & 0.8320 & 0.0015 & 0.3556 \\
\hline 浜益村 & 80.87 & 84.64 & 0.8072 & 0.8734 & 0.0548 & 0.3218 \\
\hline 要茂別町 & 49.88 & 58.21 & 0.8647 & 0.7986 & 0.2528 & 0.2280 \\
\hline
\end{tabular}

込まれた 5 市町村に対する平均時間距離等の指標を取り まとめたものである。札幌市一の流出率が増大するととも に、平均時間距離の増加及び $\mathrm{OD}$ 分布指標值の減少となっ ている。これらの結果は、旭川市を中心都市とする圈域に おいても確認されている。

\section{5. あとがき}

以上、本研究は都市間距離が長い広域分散型社会である とともに、代替交通機関が不十分で移動主体を自動車交通 に頼らざるを得ない自動車社会を形成している北海道を 対象に自動車交通流動特性について種々分析を試みた。 れらの分析を行うため、本研究では平均時間距離に加え、 他の市町村との交流規模及ひ交流範用を視覚的に、計量的 
に把握することができる指標として OD 分布指標値も考 えた。その結果、同じ平均時間距離の值を取りながら OD 分布状況が異なる市町村、各市町村が他の市町村とどの程 度の規模の交流を図っているのか、あるいはどの程度の市 町村と交流を図っているか等について視覚的に、計量的に 把握することができた。

北海道208市町村を対象に分析した結果を取りまとめる と以下のようになる。(1)平均時間距離の変化を見ると、平 均時間距離 60 分以下の市町村が 163 市町村から 119 市町 村、60 90 分の市町村が 36 市町村から 73 市町村のように 1989 年から 1999 年にか计て全体的に増加している。(2)D 分布指標值の変化で見ると、OD 分布指標 0.85 の值を境 にした市町村数の増減のように、1989 年から 1999 年にお いては减少している。(3)これら2つの指標傎からも、北海 道における 10 年間の自動車交通の変化を見ると、全体的 にトリップ長の増大が窥える。 (4)各市町村の交通流動の相 違を把握するため、2つの指標を基にクラスター分析を行

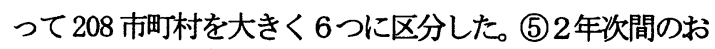
ける市町村区分の変化を通して、地方中核・中心都市への 交通量の増大とともに平均時間距離が増加している市町 村が増えている状况等についても把握することができた。

さらに、市町村間の自動車交通流動の視点からみた市町 村間の依存関係、すなわち市町村間の結節構造の視覚化に ついて考察を試みた。流出率行列及び最大流出率を基に 依存度行列を作成して、市町村間の結節構造の視覚化とと
もに、中心都市、圈域及び圏域を構成する市町村の設定等 についても考察を行った。北海道 208 市町村を対象に視覚 化を試みた結果、自動車交通の流動特性から見た北海道に おける市町村間の結節構造及び圈域の規模等を視覚的に 容易に把握することができる。また、 2 年次間の比較検討 から結節構造の変容過程についても視覚的に把握するこ とができた。

地域づくりにおいては、人々の移動の利便性や様々な地 域資源の流動性といった「モビリティ」の向上を図るとと もに、既存の行政区域を超えた広域レベルでの対応、すな わち複数市町村からなる「生活圈域」が提唱されている。 そこで今後、本研究を基礎に北海道における自動車交通の 面から見た「生活圈域」の規模・形態及ひ分布等について も考察を行っていく。

\section{参考文献}

1）桝谷・浦田・浅水 - 田村 · 斎藤（1998）、「時間距離力 らみた北海道の市町村自動車交通流動の特性について小、 土木計画学研究論文集、№. 15 pp580-591

2）桝谷・下夕村 - 浦田 - 田村 - 斎藤 (2002)、「OD 交通 からみた市町村間自動車交通流動の特性について、士 木計画学研究講演集、Vol.26

3）桝谷・下夕村・田村・斎藤 (2002)、「クラスター分析 法による結節構造の視覚化に関する研究人、日本都市計 画学会学術論文集、37、pp97-102

4）藤目節夫（1997）「交通変革と地域システム小、古今畫院

\section{北海道における自動車交通流動特性について}

合月 孝・桝谷有三・加賀屋誠一・斉藤和夫

本研究は、北海道における各市町村の自動車交通流動特性について分析を行った。れらら分析のため、 本研究においては平均時間距離とともに、他の市町村との交流規模及ひ交流範用を視覚的に、計量的に把握 することができる指標として OD 分布指標値を考えた。そして、平均時間距離および OD 分布指標值を基 に、208 市町村の自動車交通流動特性及び2 年次間の自動車交通流動の変化等について分析を試みる。また、 $2 つ$ 指標值を基にクラスター分析を行って、自動車交通流動特性から見た 208 市町村の市町村区分につい ても分析を試みた。さらに、本研究においては市町村間の自動車交通流動の視点からみた市町村間の依存度 関係、すなわち市町村間の結節構造の視覚化についても考察を試みた。

\section{Flow Characteristics of Inter-city Automobile Traffic in Hokkaido}

By Takashi AITSUKI, Yuzo MASUYA, Seiichi KAGAYA and Kazuo SAITO

This paper analyzes the flow characteristics of inter-city automobile traffic considering time distance and OD traffic flows between the cities in Hokkaido. The methodology exploits two different cumulative distribution curves to analyze the travel behavior of inter-city OD traffic flows. One curve deals with OD traffic flows generated in and attracted to each city and inter-city travel time distance. Another curve is attempted to calculate the index of distribution of OD traffic flows. The classification of 208 cities is tried from the view point of mean travel time distance and OD traffic flows by cluster analysis. Visualizing the nodal structure of inter-city in Hokkaido based on direct connection method is also conducted. 